Revue Française de Civilisation Britannique

\title{
The Rises and Falls of Adult Education on the BBC
}

$L$ 'Éducation des adultes à la BBC: entre avancée et recul

\section{Allan Jones}

\section{CpenEdition}

\section{Journals}

Electronic version

URL: https://journals.openedition.org/rfcb/7377

DOI: $10.4000 /$ rfcb.7377

ISSN: 2429-4373

Publisher

CRECIB - Centre de recherche et d'études en civilisation britannique

\section{Electronic reference}

Allan Jones, "The Rises and Falls of Adult Education on the BBC", Revue Française de Civilisation Britannique [Online], XXVI-1 | 2021, Online since 05 December 2020, connection on 06 January 2022. URL: http://journals.openedition.org/rfcb/7377 ; DOI: https://doi.org/10.4000/rfcb.7377

This text was automatically generated on 6 January 2022.

\section{(c)}

Revue française de civilisation britannique est mis à disposition selon les termes de la licence Creative Commons Attribution - Pas d'Utilisation Commerciale - Pas de Modification 4.0 International. 


\title{
The Rises and Falls of Adult Education on the BBC
}

\author{
L'Éducation des adultes à la BBC : entre avancée et recul
}

\author{
Allan Jones
}

\section{Introduction}

1 Education is included in the BBC's famous trio of objectives, "to inform, to educate and to entertain", but it has had an uneven history. John Reith, founder of the BBC, recognised that education could happen in many ways. Sometimes it happens incidentally in contexts that are not overtly educational. Reith used the term educative for this sort of education. ${ }^{1}$ From its earliest years, though, the BBC has broadcast overtly educational programmes. A distinguished example is its Schools broadcasting, although this is not covered in the present article. Another example is adult educational broadcasting - the subject of this article.

2 Adult education may be defined as education for people who are older than the upper limit of compulsory education and not enrolled in further or higher education. It can be undertaken for recreational, vocational, or professional reasons, and embodies a philosophy that learning should be a lifelong activity. At the BBC it has gone by various names, the main ones being adult education, further education and continuing education.

3 In this article I give an outline history of $\mathrm{BBC}$ adult education. When viewed in outline, the history of adult education at the $\mathrm{BBC}$ is a history of fresh attempts to get it right, followed by disappointment. A closer look reveals some remarkable successes, usually as a result of BBC staff members being seized with enthusiasm for a particular project that was both timely and educationally rewarding.

Despite its uneven trajectory, a consistent thread runs through the BBC's adult education: a strong ethical motivation. One might almost claim that $\mathrm{BBC}$ adult 
education is one of the few educational arenas where education has not been driven by a economic, pragmatic or political justifications.

\section{Inter-war adult education and the BBC}

5 The development of broadcasting in Britain coincided with a national expansion of adult education. Although the two developments were unconnected, the BBC quickly adopted adult education as a primary activity. For approximately a decade, from 1925 to 1935 , it was a major preoccupation of the BBC.

6 During the final stages of the First World War (1914-18), a British Government subcommittee recommended an expansion of adult education when peace returned. ${ }^{2} \mathrm{~A}$ distinguished educationalist has commented that: "adult education in this country has always been part of a larger movement which had as its aim the creation of a better social order...." ${ }^{3}$ In the case of the post-war expansion of adult education, the wish for a better social order can be traced to the recently ended war, in which the least privileged sections of society were required to make the greatest sacrifices. Adult education was seen as a way of rectifying, at least partly, social injustices exposed by the war.

7 For the BBC's founder John Reith, broadcasting enabled, if not a better social order (Reith was no egalitarian), at least the prospect of universal access to the best of the world's culture and thought. As one writer has argued, "public service broadcasting's fundamental goal is advancing human enlightenment." ${ }^{4}$ From this point of view, Reithian public service broadcasting was as much an ethical project as a broadcasting project, and I want to show how deeply this principle was embedded in the BBC's adult education proision.

8 Between the altruism of post-war adult education and the Reith's ethical conception of public-service broadcasting there was a natural fit. Although Reith intended much of the BBC's output to be educative, he also recognised a need for overtly educational broadcasts. ${ }^{5}$ Such broadcasts began in 1924, receiving a boost in 1928 with the publication of an influential report by a committee of enquiry. ${ }^{6}$ Although the report largely endorsed what the $\mathrm{BBC}$ was already doing, two initiatives followed: the establishment in 1929 of the BBC's weekly journal The Listener, which reprinted a selection from each week's broadcasts, and the setting up around the country of listening groups to hear and discuss educational broadcasts collectively. Underlying this practice was a conviction that "contact between mind and mind is a vital part of the educational process."

9 Wireless listening groups were central to BBC adult education for almost 20 years from 1928. Groups met at local centres, such as schools, village halls or members' homes, to listen to and discuss educational broadcasts under the guidance of a group leader. That education was seen, at least partly, as interactive and collaborative seems strikingly modern, although its advocates probably had in mind the tutorial system used in Britain's ancient universities of Oxford and Cambridge.

10 For the first three decades of the BBC's existence, educational broadcasting was confined to the radio. Television did not become significant in Britain until the later 1950s. Similarly, until the 1950s, broadcasts were live as there was not yet a practical way to pre-record and edit them. Consequently educational broadcasts from this early era cannot be heard, but fortunately transcripts of some were published in The Listener. 


\section{The Changing World}

The most ambitious Adult Education project of the 1920s and 1930s was The Changing World. This was the overall title for a project that thematically linked all adult education broadcasts from September 1931 to March 1932. As originally conceived, The Changing World was intended to examine the causes and effects of change across multiple disciplines, such as science, economics, art, politics, and so on. The timetable of The Changing World appears below. As the timetable shows, the adult education year was modelled in the academic year, with the first term from September to December, followed by one from January to March. There was also a third term from April to June, but The Changing World occupied only the first two terms of the 1931/32 academic year.

\section{Timetable for The Changing World ${ }^{8}$}

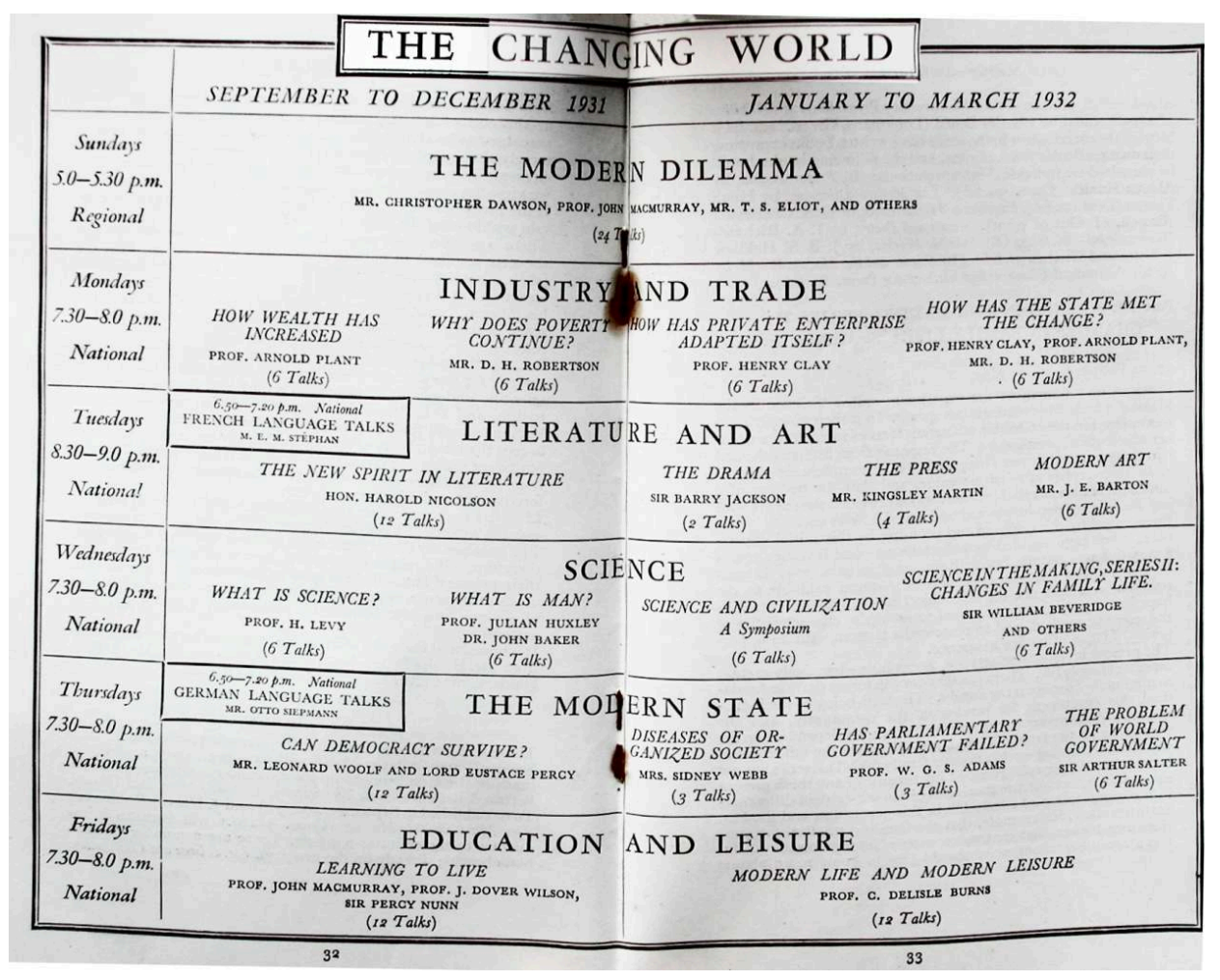

Each horizontal band of the timetable represents a particular subject area. As can be seen, most broadcasts were at 19.30 on weekday evenings - very much prime broadcasting time. Each band encompasses twenty-four half-hour talks. The entire project therefore consisted of 144 broadcasts spread over seven months, amounting to 72 hours of broadcasting time. Some distinguished British intellectuals took part: T. S. Eliot, William Beveridge, Beatrice Webb, Leonard Woolf, Julian Huxley and Harold Nicolson, for example.

14 As plans for The Changing World developed through the spring and summer of 1931, a contemporary instance of change could not be ignored. This was the financial crisis that was developing across Europe and beyond. It felt apocalyptic, and not just in Britain. The British historian Arnold Toynbee wrote: 
In 1931 men and women all over the world were seriously contemplating and frankly discussing the possibility that the Western system of Society might break down and cease to work. ${ }^{9}$

The aims The Changing World were modified as the crisis developed. The introductory booklet for the series captured the portentous mood of the times:

For some time past a sense of crisis has been abroad, which has led many to wonder what can be the outcome of our present troubles. This perplexity goes to the very roots of life, and affects us, not only in the economic and social sphere, but is allpervasive, setting its seal on art and upon literature, and upon all expressions of the human spirit. ${ }^{10}$

The intentions of The Changing World were re-framed to incorporate an analysis of the developing crisis:

In [The Changing World], an attempt is, therefore, made to face up squarely to the present situation, and to provide a survey of the many changes in outward circumstance, and in the evolution of thought and of values, which have brought into being the world as it is to-day. ${ }^{11}$

Glowing reports about the series flooded in from listening groups. ${ }^{12}$ However, the most remarkable feature of the series, in my view, was its institutional significance. For an organisation only 10 years old, the $\mathrm{BBC}$ showed remarkable maturity and selfconfidence in mounting The Changing World. An editorial in The Listener commented that such a project, on such a scale, could not have been undertaken in a book, newspaper or film. ${ }^{13}$ An article in the same issue of The Listener referred to it as a "landmark in broadcasting" and spoke of the devisers of the series as having "recognised their responsibility" and as being motivated by "a high sense of public duty". ${ }^{14}$ These responsibilities were not owed to shareholders, sponsors, proprietors or even the Government, but to the public. A participant in the series commented that speakers had been made to feel they were "shouldering a real public responsibility, that we were cooperating in a common effort to get at the truth from all sides, and to make it available for everyone, so far as we could." ${ }^{15}$ The reiteration of the words "duty" and "responsibility" in these quotations attest to a strong ethical obligation towards the public that pervaded the project. Such a deep sense of public obligation was partly a consequence of the BBC's funding arrangement (via a licence fee on radio receivers). This gave the $B B C$ an unusual measure independence, although the right to levy a licence fee was granted by Parliament and was (and remains) subject to periodic review.

It might be expected that The Changing World would have become a benchmark for all subsequent adult educational broadcasting. In fact, within a few years adult education at the $\mathrm{BBC}$ was in decline. The main reason was the failure of the group-listening scheme. In 1934, when the scheme was reviewed, there were 6.5 million licence holders and the number was growing quickly. Compared with this, the estimated maximum group audience of 20000 was insignificant. ${ }^{16}$ In essence, prime broadcasting time was being devoted to a tiny and shrinking fraction of the potential audience. Or, to put it another way, the majority of listeners to adult education broadcasts were not group listeners, and for general listeners a different kind of broadcast would have been envisaged.

The number of broadcasts intended for group-listening was gradually reduced during the following years. By 1934 there were three broadcasts per week, dropping to two in 1940 , then one in 1944, and in 1947 the scheme was closed altogether. ${ }^{17}$ 


\section{Postwar revival}

20 Despite the declining fortunes of adult education after 1934, schools broadcasting thrived. Also, following the Second World War (1939-45), Forces Educational Broadcasts (FEB), intended for military personnel awaiting demobilisation, proved so successful that the service was continued until 1952, four years beyond its scheduled closure.

21 Although FEB does not loom large in the history of the BBC, it was strikingly successful. At its height, eighteen 20-minute educational programmes were broadcast per week, amounting to 30 hours per week. This was ten times the weekly amount devoted to, for example, The Changing World. FEB broadcasts took in music, literature, current affairs languages, science, and more. Programmes were broadcast both to domestic British audiences and to personnel abroad. Several distinguished intellectuals gave broadcasts for the FEB, and broadcasts were listened to - and appreciated - by general listeners as well as military personnel. ${ }^{18}$

The successes of Schools broadcasts and the FEB suggested that another attempt at adult educational broadcasting should be made. This was initiated by the BBC employees Jean Rowntree and her assistants Joseph Trenaman and Helen Arbuthnot. They reviewed the BBC's earlier venture and diagnosed its faults: the listening-group was an artificial unit; group-listening and discussion appealed only to a small minority of the population; there was no process for discovering groups' educational requirements and translating them into broadcasts; and the functioning and growth of a listening-group was highly dependent on the group leader, and there were too few good group leaders available. ${ }^{19}$

The team set about investigating the educational needs and potential of general radio listeners. How much could such listeners learn from general programmes in the BBC's output? Between 1949 and 1951 the team carried out a series of experiments. For example, in an early experiment a recording of a 15-minute talk on electron microscopy was played to 264 listeners of mixed educational qualifications in a studio. Immediately after the talk, the listeners were asked write down everything they could recollect. Their responses were marked against a list of teaching points. ${ }^{20}$ Listeners who had understood the talk were expected to have a better recollection than listeners who had not, and their higher scores were taken to indicate better comprehension. These experiments were conducted in controlled conditions, with subjects at requisite distances apart and in a suitable ambience, lending an almost scientific feel to the investigation.

Other research techniques included questionnaires, interviews with the public, meetings with listeners, written tests, and consultations with educators and educational organisations. In all, the research involved the participation of 19000 listeners, and over 5000 tutors, principals of educational institutions and educational officials..$^{21} \mathrm{~A}$ major conclusion was that comprehension was strongly correlated with the listener's educational level. Therefore, a talk on child psychology, for example, intended for listeners who had left school at the age of fourteen needed to be very different from one aimed at university graduates..$^{22}$ This conclusion was perhaps not surprising, but was ostensibly backed by empirical evidence. Furthermore, research showed that for listeners who had few or no educational qualifications, educational material needed to be very basic indeed. 

Education) that emerged in 1952. The most significant initiative was that two of the three the existing national radio services (the Light Programme and the Home Service) would carry a number of overtly educational broadcasts interspersed among their normal broadcasts. The educational broadcasts would be created by a newly created Further Education group. This group was, naturally, expected to tailor its broadcasts to the educational level of the intended audience..$^{23}$ To some extent this differentiation by level was facilitated by the different outputs of the two services: the Light Programme was oriented towards popular entertainment and would general have a higher proportion of listeners with low educational qualifications than the less popular Home Service. A third domestic radio service operated at this time, known as the Third Programme. It specialised in such erudite fare that additional educational material was considered superfluous. ${ }^{24}$

A two-year trial of the newly conceived educational broadcasting began in the autumn of 1952, coinciding with the closure of the Forces Educational Broadcasting. The first offering was a series of twenty-minute weekly broadcasts on the Light Programme intended to give insights into to the lives of people in various European countries. In addition, the Light Programme's daily Woman's Hour included a continuous strand of educational material, and a current affairs interlude each Friday. A series for young listeners that was already established, The Younger Generation, continued three times per week in the early evening containing miscellaneous items. On the less popularly oriented Home Service, the new educational regime began with a weekly series Talking of America looking at the issues and misconceptions which "drive wedges between Americans and ourselves." ${ }^{25}$ On 17 November 1952, a weekly series The Past Around Us began in which archaeologists interpreted clues about the past from investigation of sites around Britain. ${ }^{26}$ To accompany all these educational broadcasts, a pamphlet entitled Listen and Learn was available free from the BBC. It gave a timetable of forthcoming educational broadcasts and summaries of their content, and drew attention to broadcasts that were not part of the educational offering but which were expected to be of interest to listeners who were following educational broadcasts.

Whatever the merits of these broadcasts, they were a retreat from the ambition, scale and scope of both the pre-war adult education broadcasts and the post-war Forces Educational Broadcasts. Also, to the eyes of a modern educationalist, the pre-war conception of education as a social process where meaning and understanding emerge through interaction and dialogue with peers and a tutor looks more adventurous than the post-war conception of the individual learner somewhat passively acquiring knowledge. Nevertheless, behind the new policy lay a crusading aspiration to exploit the ubiquity of radio to reach educationally disadvantaged listeners. ${ }^{27}$ The new pattern of broadcasting was reviewed after it had been operating for two years and judged to have been broadly successful. Continuation was recommended..$^{28}$

\section{Late 1950s, early 1960s}

The 1950s was a decade of declining listenership for domestic BBC radio services. Competition came from television, especially commercial television (after 1955), and also from Radio Luxembourg's English-language broadcasts. ${ }^{29}$ The latter two broadcasters offered unabashedly popular, mass-appeal programmes. High-level 
managers within the $\mathrm{BBC}$ began to speak of a need to abandon time-honoured policies that had scarcely been questioned since the founding of the BBC. In particular, the mission to educate had been, it was felt, a mission to give people what the BBC thought they ought to want. ${ }^{30}$ The outcome, in 1957, was a report entitled The Future of Sound Broadcasting in the Domestic Services. A major proposal of the report was that much minority programming (including adult education) should be shifted from the popular channels and time slots, to be replaced by more popular material. The minority material would be re-located in a new service called Network Three, operating on the same frequencies as the Third Programme but when the Third Programme was off-air in the early evening (that is, before 19.30). Following these changes, audiences for educational broadcasts fell, in one case plummeting to a tenth of what they had been. ${ }^{31}$ Jean Rowntree retired from the $\mathrm{BBC}$ in 1966. According to an obituary, at her retirement she was "uneasy that the [BBC's] broad injunction to educate had been degraded in importance." ${ }^{32}$ However, important developments were taking place both inside the BBC and in Government that were to have important repercussions for educational broadcasting. Two contexts in particular framed these developments. One was an expansion of university provision. ${ }^{33}$ The other was a proposed expansion of British television.

By the early 1960s there was the possibility of a third, and even a fourth, national television channel to add to the existing BBC television channel and commercially funded ITV (Independent Television) channel. A committee of enquiry was set up to advise the government on various television-related matters, including the possible uses for additional television channels. ${ }^{34}$ One possibility was that the fourth channel should be reserved for educational broadcasting. ${ }^{35}$ The committee recommended opening only a single new channel, and allocating it to the BBC. Nevertheless, the fact that an educational channel had been proposed reflected a growing interest the educational possibilities of television. In fact, ITV was more adventurous in this area than the BBC. In the autumn of 1963, ITV transmitted a series of first-year university lectures between 7.15 a.m. and 8.15 a.m. under the title Dawn University. The phrase University of the Air began to be used in political and educational circles to represent a possible new type of university that would use television and radio for teaching, although the phrase had a long history in the USA and elsewhere. ${ }^{36}$

\section{The Open University}

31 In 1964, the Labour Party was elected to government, and its leader Harold Wilson became Prime Minister. His declared ambition to create a University of the Air was now pursued vigorously, in the face of much opposition from all parts of the political spectrum and from educationalists, conventional universities, and even sections of the $B B C .{ }^{37}$ In the next few years, as the idea was refined, its name was changed to The Open University, the Open part of the name signifying that no entrance qualifications would be required. The Open University was intended to serve people who had not hitherto attended university but who in later life wished to obtain a degree by studying parttime at home, or who needed new qualifications in order to change their career. ${ }^{38}$ The University's pedagogical approach was also refined. Courses would be modular, and students could combine them almost at will, mixing humanities with sciences if they 
chose to. Depending on how many modules a student chose to study each year, a degree might be completed fairly quickly or might take many years.

By the time the first cohort of Open University students began studying, in January 1971, The Open University was far from being a University of the Air. Although television and radio programmes were used - produced by BBC staff and broadcast on BBC channels - they formed only a small part of the students' study materials and study time. For example, the introductory modules, which used television and radio most intensively, might require students to study for 20 hours per week; but only 30 minutes of that would be devoted to television and 30 minutes to radio. By far the greatest part of students' study time was spent studying high-quality printed course material created in the University by teams consisting of academic authors, editors, graphic designers and illustrators, and others. Later, educational software developers were added to the teams. In fact, broadcast television proved to be an awkward medium for some kinds of university teaching. The Open University's Professor of Electronics highlighted one problem: "[Television] goes too fast and cannot be slowed down to allow for thinking time. ${ }^{{ }^{39}}$ Despite the small part played by television and radio in the University's teaching, a myth persists that Open University courses consist of televised lectures. If fact students have always been able to get a good degree from The Open University despite watching few or none of the television programmes, as the present author can testify.

Although television and radio programmes occupied a small part of an Open University student's study, they formed a significant part of the BBC's broadcasting schedules. They tended to occupy the slots in the schedules that were traditional for educational broadcasts (for example, early evening on the frequencies of the least popular network). It is likely that most of their listeners and viewers would not have been students. This was a recurrent problem with adult educational broadcasting, although for The Open University it had the accidental benefit of attracting some viewers and listeners to become students. As audiocassette players and videocassette players became cheaper, radio and television programmes were increasingly distributed on tape, rather than being broadcast, but they remained a small (and decreasing) part of the University's teaching. ${ }^{40}$

Following the establishment of The Open University, traditional BBC adult education broadcasts continued, typically including foreign language courses and subjects such as literature, history, medicine and health, as well as current affairs programmes embedded in mainstream programming. Although educational broadcasting has generally maintained a low profile in the decades since the 1960s, two outstanding examples broke new ground by becoming prominent national events. They were the Adult Literacy Project and the Computer Literacy Project.

\section{Adult Literacy Project}

In the early 1970s, the number of wholly or partly illiterate British adults was estimated to be around two million. ${ }^{41}$ October 1975 saw the start of a 3-year long BBC Adult Literacy Project to help address this issue. The scale and ambition of the project exceeded even that of the pre-war The Changing World project. Beginning in October 1975, a series entitled On the Move was broadcast on BBC1 television. Each week, a new ten-minute episode was broadcast and repeated twice during the week. Fifty On the 
Move programmes were made, representing a year's worth of broadcasts. On the Move mixed comic episodes, animated films and musical items, all relevant to the life of an illiterate adult. In addition there were interviews with adults who were attempting to improve their reading and writing skills.

On the Move itself did not teach literacy, except in a very modest way. It was designed encourage viewers with reading difficulties to seek help, which they could do by calling a telephone number given at the end of each programme. ${ }^{42}$ (This telephone number was also mentioned daily on many popular radio programmes.) A caller to the number would be put in touch with a helper, who would give details of adult-literacy support available in the caller's locality. Support generally consisted of evening classes provided by local education authorities, although the BBC provided resources and a series of radio programmes to train tutors. ${ }^{43}$ Accompanying On the Move was a workbook, available from bookshops at a reasonable price. The first sections of the workbook, corresponding to the first ten episodes of On the Move, were made freely available at supermarket checkouts and industrial workplaces ${ }^{44}$ In the first year of the Adult-Literacy Project, 90000 students called the number for help.

During the second year of the project, beginning in October 1976, On the Move was retransmitted. In addition, a new series of weekly 25-minute television programmes entitled Your Move was broadcast. These were intended for more committed learners and built on the principles covered in the first-year material. These Your Move programmes were accompanied by a workbook, also called Your Move. ${ }^{45}$ During the third and final year of the project, beginning in October 1977, all materials broadcast the first two years were rebroadcast, and the support systems maintained.

The Adult Literacy Project was organisationally large and complex. Its complexities were not limited to the creation of the programmes and associated resources. The BBC's charter forbade the BBC from using licence revenue to defray expenses not associated with programme production. This meant that funding from philanthropic institutions had to be found for, in particular, the workbooks and feely distributed materials. ${ }^{46}$

As with The Changing World, the Adult Literacy Project was informed by a strong ethical sensibility. One of the project team wrote "We believe ... that [broadcasting] has a responsibility to educate society about illiteracy and to encourage those of us who are literate to help those who are not." ${ }^{47}$ Here we see again a sense of duty and obligation - and also a breadth of the ethical commitment. Helping less fortunate members of society was not enough; their plight had to be brought to the attention of more fortunate members. Furthermore the $\mathrm{BBC}$, rather than publishers, the press, cinema or other media, was seen as uniquely having these responsibilities. Partly this was because of the ubiquity of broadcasting. The team member quoted above wrote: "Broadcasting can reach people in the privacy of their own homes. It can lessen the sense of isolation which many illiterate adults, and it can publicise the sources of help." ${ }^{48}$

\section{Computer Literacy Project}

The success of the BBC's Adult Literacy Project inspired another, equally ambitious project a few years later. This was the BBC Computer Literacy Project, launched in 1982 and continuing until 1989. The project included television and radio programmes, printed course materials, software, a telephone referral service and, in a major 
departure from earlier educational projects, the commissioning of a microcomputer from a manufacturer to be sold commercially. ${ }^{49}$ practices - despite notable successes such as the Adult Literacy Project and the Computer Literacy Project. We can see that some recurring issues contributed to the chequered history of adult education. 
One issue relates to the smallness of the committed audience. The number of listeners and viewers who were dedicated students was always small relative to the number of general listeners or viewers. Educational broadcasts, like other specialist broadcasting, therefore tended to be pushed towards the least popular broadcasting times, where they attracted less attention. Even the Computer Literacy Project, which came close to having mass appeal, had its television programmes confined to the margins of the schedules, where they would be unlikely to recruit many general audience members.

Another recurring issue was the nature of the adult-education audience. Should it be regarded as a community of like minded students, who would benefit from being put in touch with each other, or should it be regarded as independent learners? From an educational point of view, communities of learners were desirable, but setting up groups and managing them almost always incurred a cost to the $\mathrm{BBC}$, and attendance was disappointing. In the Adult Literacy Project and the Computer Literacy Project the group aspect was transferred to outside bodies, indicating perhaps that other organisations were better suited to be custodians group activities.

Finally, there is a question about how best to use broadcast media. Their ubiquity makes them attractive for reaching poorly served groups, and this has motivated much educational broadcasting. But ubiquity does not necessarily make a medium good for teaching. An Open University professor was quoted as saying that broadcast television was unsuitable for teaching conceptually difficult material, and both the Adult Literacy Project and the Computer Literacy Project largely avoided using television for teaching, reserving it instead for motivation, contextualisation and discussion of issues.

Despite, all these problems, however, adult education on the BBC has had, in my view, a remarkable history. Its remarkableness lies in its firm adherence to founding principles of public service broadcasting. So often the creators of these broadcasts, or people associated with them, used the language of ethics when giving an account of their work. They spoke of duty, of responsibility towards the public, and of injunctions to educate. Furthermore, adult education on the BBC has been - remarkably - a site where education has been its own justification. It has not required justification beyond itself, though it has often been inspired by external developments and sought to illuminate them.

\section{BIBLIOGRAPHY}

Adult Education Committee, Final Report (Cmd. 321), (London, Ministry of Reconstruction, 1919).

Anon., “A Fresh Attack”, The Listener, 11 September 1952, p. 410.

Anon., "Education for Change", The Listener, 13 April 1932, p. 524.

Barnes, L. J., “Adult Education: Ends or Means?”, The Listener, 31 January 1957, pp.178-179.

BBC Written Archives Centre, Caversham, Reading. File R15/152/1, report G.41/52 "Further Education". 
BBC Written Archives Centre, Caversham, Reading. File R15/152/3, report G.73/54.

BBC Written Archives Centre, Caversham, Reading. File R15/518, "Reports on the BBC Further Education Inquiries at the Listening End".

BBC Written Archives Centre, Caversham, Reading. File R15/518, "Reports on the BBC Further Education Inquiries at the Listening End".

Blyth, Tilly, The Legacy of the BBC Micro: Effecting Change in the UK's Cultures of Computing (London, Nesta, 2012). Downloadable from: https://media.nesta.org.uk/documents/

the_legacy_of_bbc_micro.pdf. Accessed 9 July 2020.

Briggs, Asa, The History of Broadcasting in the United Kingdom, vol 2, 'The Golden Age of Wireless' (Oxford, Oxford University Press 1965).

Briggs, Asa, The History of Broadcasting in the United Kingdom, vol 4, 'Sound and Vision' (Oxford, Oxford University Press, 1979).

Briggs, Asa, The History of Broadcasting in the United Kingdom, vol 5, "Competition" (Oxford, Oxford University Press, 1995).

British Broadcasting Corporation, New Ventures in Broadcasting: A Study in Adult Education (London, $\mathrm{BBC}, 1928)$.

British Broadcasting Corporation, The Changing World (London, 1931).

Bugler, Jeremy, “Adults Without Words”, The Listener, 16 October 1975, p. 505-506.

Carpenter, Humphrey, The Envy of the World (London, Weidenfeld \& Nicolson, 1996).

Committee on Higher Education, Higher education: report of the Committee appointed by the Prime Minister under the Chairmanship of Lord Robbins 1961-63 (London, HMSO 1963) Cmnd. 2154.

Hargreaves, David, “The BBC Adult Literacy Project” in Longley, Chris (ed.) BBC Adult Literacy Handbook, (London, British Broadcasting Corporation, 1975), p. 73.

Hendy, David, Public Service Broadcasting (Basingstoke, Palgrave Macmillan, 2013).

Independent Television Authority, Educational Television. Some Suggestions for a Fourth Service (Colchester, ITA, 1961).

Jones, Allan, “Clogging the Machinery”, Media History 19:4, 2013, 436-449.

Jones, Allan, "Science in the Making: 1930s Citizen Science on the BBC", History of Education, 40:3, 2020, pp. 327-343.

Kelly, Thomas, A History of Adult Education in Great Britain (third edition) (Liverpool, Liverpool University Press, 1992).

Lawrie, Alexandra, "The BBC, Group Listening and 'The Changing World”, Media History, 25:3 2019, p. 279-291.

Lean, Thomas, "Mediating the Microcomputer: The Educational Character of the 1980s British Popular Computing Boom, Public Understanding of Science, 22:5, 2012, pp. 550-552.

MacMurray, John, “A Landmark in Broadcasting”, The Listener, 13 April 1932, p. 538.

Mullen, Eileen, “Moving On”, The Listener, 14 October (supplement), 1976, p. xi.

Pilkington, Harry, Report of the Committee on Broadcasting (London, HMSO, 1962).

Radcliffe, John, and Salkeld, Robert, Towards Computer Literacy: the BBC Computer Literacy Project 1979-1983 (London, British Broadcasting Corporation, 1983). 
Reith, John, Broadcast over Britain (London, Hodder and Stoughton, 1924).

The Times, "Sweeping Proposals for Higher Education in Robbins Report", 24 October 1963, pp. 89.

Toynbee, Arnold J., Survey of International Affairs 1931 (Oxford, Oxford University Press, 1932).

Trenaman, Joseph, “Understanding Radio Talks.” Quarterly Journal of Speech 37:2, 1951, pp. 174178.

Trenaman, Joseph, Communication and Comprehension (London, Longmans, Green and Co, 1967).

Weinbren, Daniel, The Open University: a History (Manchester, Manchester University Press, 2015).

Williams, W. E., “The Spoken Library of Learning”, Radio Times, 19 September 1952, p. 6.

\section{Electronic references}

Daily Telegraph, 5 March 2003, obituary of Jean Rowntree http://www.telegraph.co.uk/news/ obituaries/1423712/Jean-Rowntree.html, consulted 2 July 2020.

The Computer Literacy Project https://clp.bbcrewind.co.uk/history, consulted 2 July 2020.

\section{NOTES}

1. Asa Briggs, The History of Broadcasting in the United Kingdom, vol 2, 'The Golden Age of Wireless' (Oxford, Oxford University Press 1965), p.172.

2. Adult Education Committee, Final Report (Cmd. 321), (London, Ministry of Reconstruction, 1919).

3. L. J. Barnes, “Adult Education: Ends or Means?”, The Listener, 31 January 1957, pp. 178-9.

4. David Hendy, Public Service Broadcasting (Basingstoke, Palgrave Macmillan, 2013), p. 27.

5. John Reith, Broadcast over Britain (London, Hodder and Stoughton, 1924), p. 147.

6. British Broadcasting Corporation, New Ventures in Broadcasting: A Study in Adult Education, London, 1928.

7. Quoted in Tomas Kelly, A History of Adult Education in Great Britain (third edition) (Liverpool, Liverpool University Press, 1992) p. 319.

8. British Broadcasting Corporation, The Changing World (London, 1931), pp. 32-33.

9. Arnold J. Toynbee, Survey of International Affairs 1931 (Oxford, Oxford University Press, 1932) p.1.

10. British Broadcasting Corporation, Changing World, p. 1.

11. Ibid. p. 2.

12. Alexandra Lawrie, "The BBC, Group Listening and 'The Changing World", Media History, 25:3 2019, p. 286. See also Allan Jones, "Science in the Making: 1930s Citizen Science on the BBC", History of Education, 40:3, 2020, pp. 327-343.

13. Anon. "Education for Change", The Listener, 13 April 1932, p. 524.

14. John MacMurray, “A Landmark in Broadcasting”, The Listener, 13 April 1932, p. 538.

15. Ibid.

16. Data from BBC Written Archives Centre, Caversham, Reading. File R15/152/1, report G.41/52 "Further Education".

17. BBC Written Archives Centre, Caversham, Reading. File R15/518, "Reports on the BBC Further Education Inquiries at the Listening End".

18. Asa Briggs, The History of Broadcasting in the United Kingdom, vol 4, "and Vision" (Oxford, Oxford University Press, 1979), pp.736-741. 
19. $B B C$ Written Archives Centre, Caversham, Reading. File R15/518, "Reports on the BBC Further Education Inquiries at the Listening End".

20. Joseph Trenaman, "Understanding Radio Talks." Quarterly Journal of Speech 37:2, 1951, pp. 1748. Also, Allan Jones, “Clogging the Machinery", Media History 19:4, 2013, 436-449.

21. Asa Briggs, "Sound and Vision", p.744. Also Anon. "A Fresh Attack", The Listener, 11 September 1952, p. 410.

22. BBC Written Archives Centre, Caversham, Reading. File R15/518, "Reports on the BBC Further Education Inquiries at the Listening End".

23. Ibid.

24. W. E. Williams, “The Spoken Library of Learning”, Radio Times, 19 September 1952, p. 6.

25. Ibid.

26. Ibid.

27. BBC press release, "Further Education by Means of Broadcasting", 1952, quoted in Briggs, "Sound and Vision", p.747.

28. BBC Written Archives Centre, Caversham, Reading. File R15/152/3, report G.73/54.

29. Humphrey Carpenter, The Envy of the World (London, Weidenfeld and Nicolson, 1996) p. 166 and Asa Briggs, The History of Broadcasting in the United Kingdom, vol 5, "Competition" (Oxford, Oxford University Press, 1995) p. 36.

30. Quoted in Carpenter, Envy of the World, p. 167.

31. Briggs, "Competition", pp. 49-50.

32. Daily Telegraph, "Jean Rowntree" 5 March 2003. Available online at: http:// www.telegraph.co.uk/news/obituaries/1423712/Jean-Rowntree.html. Accessed 26 June 2020.

33. The Times, "Sweeping Proposals for Higher Education in Robbins Report", 24 October 1963, pp. 8-9.

34. The Pilkington Committee, established in 1960. Its report was: Harry Pilkington, Report of the Committee on Broadcasting (London, HMSO, 1962).

35. Independent Television Authority, Educational Television. Some Suggestions for a Fourth Service (Colchester, ITA, 1961).

36. Daniel Weinbren, The Open University: a History (Manchester, Manchester University Press, 2015), pp. 58-59.

37. Ibid. pp. 31-71 for a full account,

38. Ibid. p. 39.

39. Professor John Sparkes, quoted in Weinbren, Open University: a History, p. 201.

40. Ibid. pp. 200-202 for a full account.

41. Jeremy Bugler, “Adults Without Words”, The Listener, 16 October 1975, pp. 505-506.

42. David Hargreaves, "The BBC Adult Literacy Project" in Chris Longley (ed.) BBC Adult Literacy Handbook, (London, British Broadcasting Corporation, 1975), p. 73.

43. Bugler, “Adults Without Words”, pp 505-506. The programmes were called Teaching Adults to Read.

44. Ibid.

45. Eileen Mullen, "Moving On”, The Listener, 14 October (supplement), 1976, p. xi.

46. Bugler, “Adults Without Words”, p. 506.

47. Hargreaves, “The BBC Adult Literacy Project”, p. 73.

48. Ibid.

49. Thomas Lean, "Mediating the Microcomputer: The Educational Character of the 1980s British Popular Computing Boom”, Public Understanding of Science, 22:5, 2012, pp. 550-552. Also, The Computer Literacy Project < https://clp.bbcrewind.co.uk/history > consulted 2 July 2020.

50. Ibid, p. 547.

51. Tilly Blyth, The Legacy of the BBC Micro: Effecting Change in the UK's Cultures of Computing (London, Nesta, 2012), p.10. 
52. Ibid.

53. Ibid. pp.10-13.

54. John Radcliffe and Robert Salkeld, Towards Computer Literacy: the BBC Computer Literacy Project 1979-1983 (London, British Broadcasting Corporation, 1983), pp. 14, 21, 37 and 52.

55. The Computer Literacy Project < https://clp.bbcrewind.co.uk/history > consulted 2 July 2020.

56. All television programmes from the series can be viewed at this web page: https:// clp.bbcrewind.co.uk/programmes

57. Lean, "Mediating the Microcomputer", p. 550.

58. Ibid.

59. David Allen, quoted in Blyth, Legacy of the BBC Micro, p. 3.

\section{ABSTRACTS}

Adult education at the BBC has a chequered history. During the 1920s and 1930s, the BBC invested heavily in adult education, but after a promising start the scheme failed. Further rises and falls followed. The development of The Open University (founded in 1969) was seen as a new venture for adult-educational broadcasting, but broadcasts formed only a small part of its teaching material. Two extremely successful BBC literacy ventures during the 1970s and 1980s, however, showed what adult educational broadcasting at its best was capable of. Despite its chequered history, educational broadcasting has been deeply pervaded by ethical values and adheres to the founding principles of public service broadcasting.

La place de l'éducation des adultes au sein de la BBC a connu une histoire mouvementée. Au cours des années 1920 et 1930, la BBC investit lourdement dans l'éducation pour les adultes mais, malgré des débuts prometteurs, le programme se solde par un échec. La suite ne sera qu'une succession d'avancées et de reculs. Si la création de l'Open University en 1969 pu apparaître comme une initiative propice au développement de la radiodiffusion éducative à destination des adultes, les programmes diffusés ne constituent finalement qu'une part minime du matériel pédagogique proposé. Au cours des années 1970 et 1980, la BBC lance deux projets qui furent auréolés de succès, symboles de ce que la radiodiffusion éducative pour adultes pouvait produire dans sa forme idéale. Malgré cette histoire en dents de scie, la radiodiffusion éducative est restée pétrie de valeurs éthiques est s'est montrée fidèle aux principes fondateurs du service public de l'audiovisuel.

\section{INDEX}

Mots-clés: $\mathrm{BBC}$, éducation des adultes, alphabétisation pour adultes, opération de maitrise de l'outil informatique, Open University

Keywords: adult education, adult literacy, BBC, computer literacy, educational broadcasting, Open University 


\section{AUTHOR}

\section{ALLAN JONES}

Allan Jones is a Senior Lecturer in the School of Computing and Communications at The Open University, and a former editor in the University's Publishing Division. He has written teaching material on electronics, communications technology and music. His research centres on the history of science and technology, and he has published articles on the history of science broadcasting at the BBC. 